\title{
VALUATION STANDARDS FOR COMMERCIAL BANKS IN THE FINANCIAL THEORY AND THEIR ANALYSIS
}

\section{Milan Hrdý}

\begin{abstract}
This article focuses on bank valuation standards as some recommended steps how to evaluate some concrete commercial bank by the market value. Different approaches, methods and models were analysed and the final recomendations were stated. Basic valuation approaches such as the income approach, the market-based approach and the asset-based approach used for traditional entreprises valuation are recommended also for the commercial banks valuation, but it is necessary to adjust them according to some specifics of banks. After the precise analysis it is possible to recommend the application of Market-Based Valuation or in other words Relative Valuation in the combination with Bond Pricing Model. This is the best choice, but only in case there is some comparable bank or comparable transaction available. In the opposite case it is possible to recommend the application of the income approach based on DDM or DCFE in the combination with Bond Pricing Model or with Excess Return Model. Asset-Based Valuation could be used in case of valuation of different type of bank's asset or in case of the valuation for accounting or tax purposes. The most important problem lies also in the identification of the coefficient beta that oscillates in case of the large maturity banks according to the "magic one".
\end{abstract}

Keywords: valuation, commercial bank, standards models

JEL Classification: G32, G21

\section{Introduction}

The valuation standards for banks represent some basic instructions how to act, but they maintain the application of a subjective approach, especially when it comes to the risk evaluation, the estimation of the future market potential and so forth. These valuation standards are not for the time being codified rules such as the valuation standards for different types of assets and International (2011) or European (2016) Valuation Standards state only some common approaches for the income valuation, the relative valuation and for the identification of the discount interest rate by the process of valuation of some entrepreneurial unit. These standards for banks are the same as for the different types of assets and they are developed within the "meaning of best practice" and the same is as in the case of different types of assets "as the results of trials and errors with the real transactions" (Krabec, 2014, p. 533). The principles of these rules of conduct come into existence from the economic

* Milan Hrdý, Faculty of Finance and Accounting, University of Economics in Prague, Prague, Czech Republic (hrdy@svse.cz).

This paper was prepared with the institutional support of the Faculty of Finance and Accounting University of Economics in Prague IP 100040. 
theory that according to the Hayek (1994) enables to avoid conflicts and eliminates some sources of mistakes and doubts. Also according to Hayek (1994) the uncertainty cannot be eliminated entirely. This corresponds to the above-mentioned subjective approach to risk valuation or to the estimation of the future market potential. There were also great differences among different valuation assessments in the process of the valuation of the same bank by the different appraisals or appraisal companies and this situation must be eliminated by some valuation standardization for commercials banks.

So this article focuses on the bank valuation standards as some recommended steps how to evaluate some concrete commercial bank on the basis of mainly the market value which reflects some expectations of the average market's participants. This market value could be identified by some objective steps and also by some subjective decisions of the concrete appraisal.

Three most important approaches are known for the purpose of the valuation of the enterprises; the income valuation, the market-comparison valuation and the asset-based valuation. Are these methods suitable also for banks? The asset-based valuation is only the subsidiary method of valuation, but it could be easier than in case of the traditional enterprises because most items of the property of banks are valued in real (fair) values and it is not necessary to adjust them for their real equivalent. But this method is suitable only for the purpose of the valuation for accounting and tax purposes and not for the valuation of banks as whole companies. But the value of banks' assets could be useful also for the methods of the so called Obligation Pricing Model that will be analysed later. The market-based method which is often called as Relative Valuation can be used in a similar way as in case of the traditional enterprises if it is found some comparable bank or some comparable transaction. The income approach is the most important approach to the valuation of the enterprises and in case of banks the situation is the same. The income valuation in fact is the only valuation which takes into account the future potential of the institution being valued. But traditional enterprises are usually valued by the free cash flow method which is not suitable for the financial institutions that administer also money of their clients and have above mentioned great indebtedness and so free cash flow equity could be the better solution.

The problem of the identification of the valuation standards for the banks lies in the fact that there are relatively very limited different opinions and publications to this problem in the Czech Republic as well as abroad. If there are some approaches it is necessary to judge them and to show their strengths and weaknesses and their possible application in practice. So the aim of this article is to elaborate and research of the different published opinions to the bank valuation and to analyse and judge of their use in practice. The methodology used would be based on some analysis of these previous opinions, on their comparison and in conclusion on the final synthesis which could lead to the judgement if the valuation standards for the banks companies do matter.

\section{Different Model Approaches to the Valuation of Banks}

Firstly, only common and basic information about this problem was presented. Miller (1995) offers only some description concerning the application of the valuation methods 
for enterprises on banks. These valuation methods are the income approach, the asset-based approach and the market-based approach.

The income approach is analysed only for the purpose of the local banks without some investment activities and only the stabilized level of income and the discounted future income method are available. The process of planning is based on the projection of the future income levels or using "time series equations to forecast components of total income of business" (Miller, 1995, p. 35). As the alternative Miller (1995) offers dividend capitalization model that is based on the expected dividends. According to Miller (1995, p. 43) this model can be used for banks which "does not pay dividends, but has the financial capacity to do so". The dividend capacity concept plays according to Miller (1995, p.44) very important role in case of the valuation of "banks for the acquisition purposes".

Some relatively very interesting information was published by Miller (1995) in case of using assets-based method where the special methods for some specific intangible bank assets are presented. They are mainly the methods concerning the valuation of the so called "core deposits" that represent some stable amount of deposits which are available for the bank as the most important financial source. These methods are the cost savings approach and the future income approach (Miller, 1995). The first approach is based on the span between the costs associated with the core deposits and the costs of the alternative financial sources available (Miller, 1995). The second one is then based on the identification of the net future incomes that are possible realized by investing these core deposits. But the importance of the so called "core deposits" is very strongly decreasing because the alternative financial sources are cheap nowadays and the above mentioned span is very low or zero.

Rezaee (2001) extended the knowledge about the valuation of the banks and considerably elaborated some basic methods for the bank valuation such as income approach, marketbased approach and asset-based approach.

In case of the income approach Rezaee (2001) presents the same possibilities as Miller (2001), but on the more elaborated level with some more detailed identification of the Discounted Future Income Method and Dividend Capitalization Model. Also the valuation of different types of bank assets and liabilities is elaborated in detail. For example the recommended techniques for the identification of the measuring of the life period of intangible assets are by Rezaee (2001) analysed.

Some very interesting part of the Rezaee (2001) publication is the analysis of the complications that could arise in case of valuation of the real world's bank. Rezaee (2001, p. 215) presents as the most important problems "bank experiencing recent losses, banks with uncertain future loan loss exposure, highly leveraged banks and initial public offering". Although Rezaee's publication is relatively old, some information is very topical, for example the valuation of bank with some recent losses or banks with uncertain future loan exposure. This is also the actual situation mainly in case of banks in Italy and Spain. Rezaee (2001) offers the valuation of bank with losses on the base of net assets value or on the base of the income approach, but only if some restructuring is possible and new income can be realized.

Damodaran (2012) offers Dividend Discount Model, Excess Return Model, relative valuation and assets-based valuation. The dividend discount model and the excess return 
model are both based on earnings and not on cash flows. Damodaran (2012, p. 596) argues that "banks have little or none net capital expenditure needs and that there is practically no working capital". If there is possible to estimate some future dividend payments it is possible to use traditional model with cost of equity and expected growth rate in perpetuity. The excess return model has the following form:

Value of Equity = Equity Capital Invested Currently + Present Value of Expected Excess Returns to Equity Investors.

Relative Valuation is based by the two important multipliers, traditional P/E ratio and Priceto Book-Value Ratio. The assets-based valuation is principle based on the net assets value where it is necessary to evaluate the bank assets including the different types of bank's securities.

Schoon (2012) offers two basic bank valuation models, Residual Income Valuation Model and the Continuing Value. The Residual Income Valuation Model is derived from Equation 2 (Schoon, 2012, p. 20):

$$
V_{t}^{e}=B_{t}^{e}+\sum_{i=t+1}^{\infty} \frac{E_{t}\left[\text { Earnings }_{i}-\left(r_{e} \times B_{t}^{e}\right)\right]}{\left(1+r_{e}\right)^{i}},
$$

where $B_{t}^{e} \quad$ book value of a bank per share at time $t$,

$E_{t} \quad$ expectation based on information available at time $t$,

Earnings $_{i}$ earnings for period $i$,

$r_{e} \quad$ required return of equity capital,

i period,

$t$ time.

The Continuing Value could be derived from Equation 3 (Schoon, 2012, p. 21):

$$
V_{t}^{e}=B_{t}^{e}+\sum_{i=t+1}^{\infty} \frac{E_{t}\left[\text { Earnings }_{i}-\left(r_{e} \times B_{t}^{e}\right)\right]}{\left(1+r_{e}\right)^{i}}+\left(\frac{\frac{R I_{3} \times(1+g)}{\left(r_{e}-g\right)}}{\left(1+r_{e}\right)^{3}}\right),
$$

where $B_{t}^{e} \quad$ book value of a bank per share at time $t$,

$E_{t} \quad$ expectation based on information available at time $t$,

Earnings $_{i}$ earnings for period $i$,

$r_{e} \quad$ required return of equity capital,

$i$ period,

$t \quad$ time,

$R_{3} \quad$ residual income at the end of the 3 years,

$g \quad$ the expected long term growth rate.

Equation 3 shows that the real period for the income planning is stated for the period of 3 years, whereas the common habitual practice in the process of valuation is 5 years. 
Also the very interesting thing emerging from the above-mentioned equations is the fact that the final valuation of the bank is the combination of the book value (net assets value) and the income approach. Equation 3 is made up of three addends where the first represents the book value, the second residual value and the third the continuing value on the goingconcern principle. This model uses in case of the income approach earnings. There are also the different theories that for the purpose of the income valuation recommends the cash flow as in case of traditional enterprises.

Coppeland, Koller and Murrin (2000) define this cash flow as the cash from the operations and the sources reduced by their usage.

Cash flow from the operations = interest incomes + fees incomes -

interests costs - depreciation - taxes,

Sources $=$ gross due loans - depreciations in cash,

Usage = the new loans + the increase of bank's securities + the increase of reserves the decrease of deposits - the decrease of external debt-the repurchase of assets.

Some critical review was presented also by Deev (2011) by summarizing the advantages and disadvantages of the basic valuation approaches such as the income approach, the marketbased approach, the assets-based approach and contingent claim valuation. The results of his critical review show that the methodology of bank valuation is significantly difficult and insufficiently studied. Deev (2011) also mentions some problems with the financial crisis and its negative influence on the bank valuation and also the problems with the application of the income method and the market-based method in the emerging markets due to the lack of market information.

An Empirical Comparison of Intrinsic Valuation Methods was published by Leister (2015) where the comparison of the market value and intrinsic value was realized. Leister (2015) accepts for the income approach the valuation based on the two-stage dividend discount model and for relative valuation the multipliers $\mathrm{P} / \mathrm{E}$ ratio and $\mathrm{P} / \mathrm{BV}$ ratio. Also Excess Return Model could be considered by Leister (2015) as an acceptable solution for the bank valuation. The most important contribution of Leister (2015) was the comparison of the market value of chosen banks within the European Union and the intrinsic values calculated by the different methods. His conclusion shows that "no model is superior over another" and that "some valuations methods seem to have a higher explanatory power than for others". According to Leister (2015) Discounted Dividend Approach relatively the most reflected the stock price, but, on the other hand, this approach is not suitable for the banks with the impact of financial crisis that did not generate profit and did not pay dividend.

The most interested study presented Titko and Lace (2012) that develop a mathematical model as an alternative to existing company's valuation models. This alternation was chosen because in case of using the traditional present value of expected dividend it is necessary to predict "value of future dividends using retrospective information". Also the great problem occurs if banks do not pay dividends or pay dividends irregularly. The models 
values were finally compared to the real value of banks based on average $\mathrm{P} / \mathrm{B}$ ratios. Titko and Lace (2012) selected the indicators from the analytical reports of European Central Bank, International Monetary Fund and Financial and Capital Market Commission. Indices for the correlation analysis were divided into five groups of ratios where the first group was represented by profitability and efficiency indices, the second group by income and cash flow statement indices, the third by balance sheet indices, the forth by assets quality and the fifth by capital adequacy. The research of Titko and Lace (2012) was conducted by the previous study of Titko and Kozlovskis (2011). As the most valuable factors were identified by Titko and Lace (2012) return on assets, return on equity, non-performing loans to total loans, provisions and provisions to loans, interest income to interest expenses, net interest income to total income and cost-to-income ratio. The authors (Titko and Lace, 2012) using different combination of variables developed 23 variants of a model in total and used financial indices from Latvian banks' reports of 2010. The optimal model was expressed by Equation 7 (Titko and Lace, 2012):

Bank Value $=2,038 \times$ provisions of doubtful loans $+3,693 \times$ net interest income.

According to Titko and Lace (2012) "R-squared of the model is equal to 0.922, indicating that $92.2 \%$ of the variability in the bank value is explained by this model". Finally, the very interesting information was published by Titko and Lace (2012) by comparing the values of the chosen Latvian banks calculated by this model to the values calculated on the basis of the traditional $\mathrm{P} / \mathrm{E}$ ratio. I am afraid there were identified a relatively great differences between both approaches where for example according to Titko and Lace (2012) in case of seven banks estimated value and market data exceeds $50 \%$ and even in three cases exceeds $80 \%$. So it points out that despite a relatively great statistical significance the offered model does not provide reliable results and so it is not possible to use them for the practice of commercial banks valuation. Maybe the period of five years was not sufficiently long and may be the negative role plays also the fact that the time period also involved two years of financial crisis. And also according to the view of the author of this article it is not possible to identify in real practice the value of the concrete commercial bank only according to the two factors (provisions and net interest income) otherwise they are relatively very important.

The most elaborated and relatively new procedure of commercial banks valuation was described by Massari, Gianfrate and Zanetti (2014). They offer the possibility of the income valuation, relative valuation and assets-based valuation. Discounted Returns Models are offered by Massari, Gianfrate and Zanetti (2014, p. 107) in three versions: Dividend Discounted Model, Discounted Cash Flow to Equity Model and Excess Return Model.

Dividend Discounted Model is based on the value of shares which depends on the expected dividends the shareholders will receive in future (Massari, Gianfrate and Zanetti, 2014, p. 111). This approach has three modifications, one-stage Gordon Growth Model, Two-Stages Growth Model and Year-by-Year Growth Models. These models differ in the number of periods which could be solved and in the estimation of $g$ (expected 
growth) for these different periods. This approach exits, broadly speaking, also in case of the nonfinancial companies.

Discounted Cash Flow to Equity Model represents some modification of the FCFE model for nonfinancial companies where there are two the most important differences. Firstly "financing and investments are key elements of bank core activity and cannot be effectively disentangled from the bank's comprehensive income" (Massari, Gianfrate and Zanetti, 2014, p. 118). Secondly according to Massari, Gianfrate and Zanetti (2014, p. 118) it is necessary to take into consideration the fact that they are regulatory capital requirements that could be retained by the bank and cannot be distributed for the shareholders. But this argumentation is very arguable because according to the author's view the capital requirements in the contemporary banks highly exceed the capital requirements not only according to the Basle II, but also according to the Basle III.

Excess Return Model is based on Equation 8 Massari, Gianfrate and Zanetti (2014, p. 121):

$$
\text { EquityValue }_{0}=\text { Equity Capital }_{0}+\sum_{t=1}^{\infty} \frac{\text { Excess Return }_{t}}{\left(1+k_{e}\right)^{t}},
$$

where $k_{e}$ the cost of equity,

$t$ relevant year.

Excess Return is defined according to Massari, Gianfrate and Zanetti (2014, p. 121):

$$
\begin{gathered}
\text { Excess } \text { Return }_{t}=\left(\text { ROE }_{t}-k_{e}\right) \times \text { Equity Capital }_{t-1}= \\
=\text { Net Income }_{t}-\left(k_{e} \times \text { Equity Capital }_{t-1}\right) .
\end{gathered}
$$

For the purpose of income valuation the identification of cost of equity is necessary. Massari, Gianfrate and Zanetti (2014, p. 108) offer the traditional CAPM, but the very interesting thing is their coefficient $\beta$ identification. The discussion about the convergence of this coefficient to the value of 1.00 is well known and this identification is presented in the following way (Massari, Gianfrate and Zanetti (2014, p. 110):

$$
\text { Adjusted beta }=\text { Observed beta } \times 0.67+1.00 \times 0.33 .
$$

This approach is based on the previous research provided by Blume (1975), but this research is relatively very old and for that reason not so acceptable. But this formula is in practice not bank-specific and is generally accepted also in different cases, for example in financial software such as Bloomberg.

The market-based valuation, called by Massari, Gianfrate and Zanetti (2014) "Relative Valuation" is based on the same principles as it is in case of nonfinancial institutions. Market multiples are mainly P/E and P/BV (book value) that are used also for nonfinancial institutions. It is offered also some "indirect multiples" (Massari, Gianfrate and Zanetti, 2014, p. 107) such as P/Revenues and P/Deposits, but their use is also very arguable.

Also some important information could be the considerations by Massari, Gianfrate and Zanetti (2014) concerning the type of approaches used for the final bank's valuation. They mentioned (2014, p.143) that it is useful to value separately each business and then to 
identify the final value of bank by the sum of all the businesses. For the commercial banking valuation the income approach represented by DCFE is recommended, for the investment banking relative valuation by the use of the $\mathrm{P} / \mathrm{E}$ multiple and for the asset management then P/AUM valuation (Massari, Gianfrate and Zanetti, 2014, p. 144).

Finally it is possible to highlight that the approach of Massari, Gianfrate and Zanetti (2014) is to date the more complex and sophisticated view concerning commercial banks valuation otherwise some minor remarks can emerge.

Hrdý (2011) recommends the method known from practice as Bond Pricing Model that is represented by the combination of the income and property method. It is based on Equation 11 (Hrdý, 2011):

$$
M V=\frac{R O E}{C O E} \times N A V,
$$

where $M V$ market value of the financial institution (bank),

$R O E$ return on equity,

$C O E$ cost of equity,

$N A V$ adjusted net value of assets (market value of assets - liabilities).

This model is mainly suitable for the commercial banks valuation. The advantage of this method lies in a relatively easy way to identify the entry data, but this method in comparison with the traditional income approach does not take into account the future potential of the commercial bank being valued and so the results by using of this method are lesser than in case of using the income method. The income method is represented by Hrdý (2011) by two phase method based on the removable net profit or the dividend potential.

As the most interesting could be the identification of the discount interest rate for the income approach of valuation, mainly the identification of the coefficient beta in case of using CAPM. This coefficient is very often recommended for the larger and maturity banks equals to one (Damodaran, 2009), but in practise the situation is relatively more complicated. The most important fact that is necessary to take into account is relatively large differences between beta coefficient of the commercial activity and beta coefficient from the investment activity. There are also some studies concerning coefficient beta, for example Stever (2007, p. 238) that provides evidence that "beta riskiness rather than leverage affects bank beta". King (2009, p. 72) proved that beta coefficient is declining which is explained by the "lower covariance by bank stock returns with market returns".

The process of commercial banks valuation is also determined by the risk management that can influence the real value of bank assets, by the identification of the above mentioned discount interest rate and also by CAR (Capital Adequacy Ratio). This possible allocation to Capital Adequacy Ratio must be deducted from the net income. But under the conditions of the Czech commercial banks it is outside the reality because their ratio is about $17 \%$ and the requirements are only $8 \%$. Either the new future requirements according to the Basel III cannot influence this situation because $13 \%$ is also less than $17 \%$. The other situation is in Europe where some banks have relatively a lot of problems and according to Š́torová and Teplý (2014, p.158) "the impact of the Basel III regulation on the value of bank shares 
will probably be perceived negatively by the market, which could be reflected in a drop in the market value of the shares of the observed banks". From the general point of view the Basle III regulation including CAR could lead in to a drop in the market value of Czech banks, because of some incremental costs and because of some complicated process of the implementation of the new rules. Some specific problems were also with NSFR.

\section{Recommended Valuation Approaches}

There are some above mentioned approaches and models for the commercial banks valuation, but for the final identificatication of the recommended valuation standards it is necessary to solve some crucial problems.

The first problem consits in identifying the fact if some models or individual methods could be recomended for the final valuation of the commercial bank. The experiences of Titko and Lace (2012) and Leister (2015) show that some individual models derived from individual empirical studies are not suitable for the final valuation because they were identified under some concrete conditions and for some specifics conditions. The study of Titko and Lace (2012) even confirmed that either for some concrete purpose such as the valuation of Lithuanian banks is not the empirical model suitable. Let's be not mistaken that the names "model" are used in different approaches, for example Excess Return Model by Massari, Gianfrate and Zanetti (2014) or by Damodaran (2012) or The Residual Income Valuation Model according Schoon (2011). These models are in reality some sophisticated approaches that can be used for the valuation of universal commercial bank. The solution to the first problem so lies in the valuation of bank by some individual approaches chosen by the appraisal. Maŕík (2011, p. 423) states that "in practice the rule is acceptated at least two methods of valuation to use". There is no reason to use some different practices for the commercial banks valuation. The problem lies in the identification of some suitable method that could be used for the commercial banks valuation. All approaches, the income approach, the relative or market-based approach and also asset-based approach are suitable, but each for some different situations. The asset-based approach is suitable for the valuation of some part of the bank or some concrete asset or for the accounting or tax purpose. The market-based or relative valuation is convenient when some comparable banks or transactions are available. The income approach is very demanding for the stategic analysis and for the final financial plan, but, on the other hand, the most testifying because it takes into account the future potential of the bank being evaluated. Because there were before mentioned great differences among different valuation assessments in the process of the valuation of the same bank by the different appraisals or appraisal companies, Bond Pricing Model could be very suitable as one of the method chosen because it could be so fixed to the lower boundary of the valuation and also some concrete figure where approximately the value can be find. Bond Pricing Model could be than completed by some income method that can take into consideration the future potential of evaluated bank.

The second problem lies in the identification of some income methods which could be suitable for the realization of the income approach. The method FCFF (Free Cash Flow Firm) that is very often recommended for the traditional enterprises and that is recommended 
in some adjusted form by Coppeland, Murrin and Koller (2000) can be eliminated because it does not correspond to the specific of the commercial banks mainly to the only marginal position of the cash flow statement in banks' accounting. Then it is necessary to identify if FCFE (Free Cash Flow Equity) recommended by Rezaee (2001) or by Damodaran (2012) or by Massari, Gianfrate and Zanetti (2014) or Leister (2015) or Discounted Dividend Model (DMM) recommended by Miller (1996) or by Massari, Gianfrate and Zanetti (2014) or by Leister (2015) or dividend potential (net removable income) by Hrdý (2011) or Excess Return Model recommended by Damodaran (2012) or by Massari, Gianfrate and Zanetti (2014) are acceptable for the practice of the commercial banks valuation.

FCFE method could be applicable if some specifics of the commercial banks could be strictly taking into account. DDM method works with some expected dividends and this approach can be used only in case of prosperous banks as recommended for example by Leister (2015) or indirectly by Titko and Lace (2012). For that reason it could be more reasonable the so called dividend potential recommended by Hrdý (2011) that considers future dividends that can be at the most paid. On the other hand, the very arguable question is the name "net removable income = dividend potential" published by Hrdý (2011) because this net removable income is identified from the adjusted planned profit and loss statement and not on the base of FCFE. So the approach by Hrdý (2011) is a bit closer to DDM model despite there is a dividend potential and not real dividend according to DDM approach and is much more close to Miller's (1995) approach.

The most important and very interesting method is the so called Excess Return Model that is presented for example by Massari, Gianfrate and Zanetti (2014) or by Damodaran (2012). It is in reality the approach that consists of the two parts. The first is represented by the value of capital invested by the owners of bank and the other by so called excess return that was defined in previous text. This approach is relatively very close to Bond Pricing Model presented by Hrdý (2011) because it works with return on equity and cost of equity. So the excess here means the difference between both items and in case both items are equal than the value of commercial bank equals the value of equity. It is very similar to the situation in case of Bond Pricing Model because in this case the value of bank equals to net assets value that is defined as the difference between assets value and value of liabilities. So Excess Return Model could be used instead of Bond Pricing Model as some lower boundary of valuation.

The third problem lies in the identification of the discount interest rate for the income valuation approach. Almost all the approaches came to an agreement that it is necessary to use the cost of equity. The problem consists of the identification of this cost. There are some possibilities such as dividend growth model or CAMP or modular approach. All the approaches are in reality acceptable and they depend on some concrete conditions and possibilities that are for the appraisal available. The most interesting part of this problem is the identification of the beta coefficient. The most important question is represented by the decision if to identify this coefficient with difficulties or if to choose the so called "magic one". As it can be derived from Damodaran approaches (2009 and 2012) the magic one is suitable to use only if there is a stable mature commercial bank on some stable market. Also 
some very important role plays the share of investment and commercial activity because coefficient beta is higher for the investment activity that for the strictly commercial activity. For that reason it could be recommended the approach by Hrdý (2012) that proposed Equation 12:

$$
\beta=\beta_{K} \times P+\beta_{I} \times(1-P)
$$

where $\beta$ final coefficient beta,

$\beta_{I} \quad$ coefficient beta for investment activity,

$\beta_{K} \quad$ coefficient beta for commercial activity,

$P \quad$ share of the commercial activity on the total incomes of bank.

The forth problem lies in the choice of the best multiplier in case of using relative valuation or market-based valuation. The first problem is to choose some suitable bank or transaction, of course, but in case of success it is necessary to use just right multiplier. The most used is the traditional multiplier P/E (Price/Earnings Ratio) that was used also by Titko and Lace (2012) and is recommended also by Rezaee (2001), by Damodaran (2012), by Hrdý (2011) and by Massari, Gianfrate and Zanetti (2014). The same authors recommend also the traditional multiplier M/B (Market to Book Value Ratio). The very debatable could be also the next multipliers, for example some offered by Massari, Gianfrate and Zanetti (2014) Price/Revenues and Price/Deposits. But finally it is possible to recommend as it is in case of the traditional enterprises to use more multipliers and to identify their final average value.

\section{Conclusion}

This article focussed on the bank valuation standards as some recommended steps how to evaluate some concrete commercial bank on the basis of mainly the market value which reflects some expectations of the average market's participants. This market value could be identified by some objective steps and also by some subjective decisions of the concrete appraisal. Different published opinions to the commercial banks valuation were elaborated, researched, analysed and their use in practice was judged.

It was stated that some basic valuation approaches such as the income approach, the market-based approach and the asset-based approach used for traditional entreprises valuation are recommended also for commercial banks valuation, but it is necessary to adjust them according to some specifics of banks. The problems lie in the fact that there are relatively few opinions and theories concerning the valuation of banks and that they are great differences among different appraisals of the same commercial bank being valued.

So the approaches by Miller (1995), by Rezaee (2001), by Copeland, Koller and Murrin (2000), by Hrdý (2011), by Damodaran (2012), by Schoon (2012), by Massari, Gianfrate and Zanetti (2014) and by Leister (2015) and the practical studies by Deev (2011) and Titko and Lace (2012) were analysed and evaluated.

It was proved that some special and individual models for commercial banks valuation were not suitable and that it is necessary to use some individual method 
in the convenient combination. In case of Income Approach FCE method as well as the approach by Copeland, Koller and Murrin (2000) was refused and DDM and FCFE methods were recommended in combination with Bond Pricing Model or Excess Return Model. The problem of the identification of the of the discount interest rate was also analysed and CAPM method was recommended. The most important problem lies also in the identification of the coefficient beta that oscillates in case of the large maturity banks according to the "magic one". For that reason the approach presented by Hrdý (2011) where "the magic one" was adjusted by the type of bank and also by the type of market could be suitable.

In conclusion it is possible to recommend the application of the market-based valuation or in other words Relative Valuation in the combination with Bond Pricing Model. This is the best choice, but only in case there is some comparable bank or comparable transaction available. In the opposite case it is possible to recommend the application of Income Approach based on DDM or DCFE in the combination with Bond Pricing Model or with Excess Return Model. This combination is also very often used in practise of the commercial banks valuation by different appraisals in the Czech Republic. But it is very complicated to obtain some concrete data about practical use of the different methods of Czech appraisals, because it is the object of the trade secret. In general in the world market-based valuation is used if there is a relatively developed market with a lot of necessary information and comparable banks or comparable transactions. Asset-based valuation could be used in case of valuation of different type of bank's asset or in case of the valuation for accounting or tax purposes.

\section{References}

Blume, M. (1975). Betas and Their Regression Tendencies. The Journal of Finance, 30(3), 785-795, https://doi.org/10.2307/2326858

Copeland, T. E., Koller, T., Murrin, J. (2000). Valuation: Measuring and Managing the Value of Companies. $3^{\text {rd }}$ Edition, New York: John Wiley and Sons. ISBN 978-0471361916.

Dammodaran, A. (2009). Valuing Financial Service Firms. Dammodaran C2009. [online] [Retrieved 2016-06-17]. Available at: http://pages.stern.nyu.edu/ adamodar/

Dammodaran, Aswath (2012). Investment Valuation. Tools and Techniques for Determining the Value of Any Asset. 3rd ed. New Jersey: John Wiley \& Sons, USA. ISBN 978-1-118-01152-2.

Deev, O. (2011). Methods of Bank Valuation: A Critical Overview. Financial Assets and Investing, 2011(03), 33-44.

EVS (2016). European Valuation Standards. 8th Edition. Brusel: TEGoVA, ISBN 978-90-81-90-60-1-2.

Hayek, F. A. (1994). Právo, zákonodárství a svoboda. Nový výklad liberálních principů spravedlnosti a ekonomie. (Law, Legislation and Freedom. The New Interpretation of the Liberal Principles, Justice and Economics.) Prague: Akademia. ISBN 80-200-0241-3.

Hrdý, M. (2011). Oceňovací standardy pro banky a další finanční instituce. (The Valuation Standards for Banks and the Other Financial Institutions.) Oceňování, 4(3), 21-37. 
Hrdý, M. (2012). Problematika diskontní úrokové míry při oceňování bank a dalších finančních institucí. (The Problems of the Discount Interest Rate When Valuing Banks and Other Financial Institutions.) Oceňování, 5(3), 14-26.

IVS (2011). International Valuation Standards. London: IVSC. ISBN 978-0-9569313-0-6.

King. M. R. (2009). The Cost of Equity for Global Banks: A CAPM Perspective from 1990 to 2009. BIS Qarterly Review, 59-73.

Krabec, T. (2014). Asset Valuation Standard. A Functional - Institutional Approach. Prague Economic Papers, 23(4), 531-540, https://doi.org/10.18267/j.pep.511

Leister, F. (2015). Valuation Methods for Banks: An Empirical Comparison of Intrinsic Valuation Methods for Banks. Bachelor Thesis IUBH School of Business and Management, Bad Honef, Germany, https://doi.org/10.13140/RG.2.1.4194.4483

Mařík, M. et al. (2011). Metody oceňování podniku. Proces ocenění. Základní metody a postupy. (The Methods of Enterprises Valuation. The Process of the Valuation. Basic Methods and Processes.) Prague: Ekopress, s.r.o. ISBN 978-80-86929-67-5.

Massari, M., Gianfrate, G., Zanetti, L. (2014). The Valuation of Financial Companies. Tools and Techniques to Value Banks, Insurance Companies, and Other Financial Institutions. London: Wiley \& Sons Ltd., Printed by TJ International Ltd in Great Britain. ISBN 9781118617335.

Miller, W. D. (1995). Commercial Banks Valuation. New York: John Wiley and Sons, Inc., ISBN 0-471-12820-1.

Rezaee, Z. (2001). Financial Institutions, Valuations, Mergers, and Acquisitions. $2^{\text {nd }}$ Edition. New Jersey: Wiley John and Sons. USA. ISBN 0-471-39449-1.

Schon, N. (2012). What's a Bank Worth? Realistic Valuation of the Financial Industry. London: Spiramus Press, Ltd. ISBN 978-1907444-05-0.

Stever, R. (2007). Bank Size Credit and the Sources of Bank Market Risk. BIS. Working Papers No. 238, Basel, https://doi.org/10.2139/ssrn.890658

Š́torová, B., Teplý, P. (2014). The Level of Capital and the Value of EU Banks under Basel III. Prague Economic Papers, 23(2), 143-161, https://doi.org/10.18267/j.pep.477

Titko, J., Kozlovskis, K. (2011). Development of Bank Value Model. in: The 15th World MultiConference on Systemics, Cybernetics and Informatics (WMSCI 2011): Proceedings. Vol.1, United States of America, Orlando, 19-22 July, 2011. Winter Garden: International Institute of Informatics and Systemics, 143-148. ISBN 978-1-936338-29-0.

Titko, J., Lace, N. (2012). Valuation Models for Latvian Banks. Proceedings from the $7^{\text {th }}$ International Scientific Conference "Business and Management 2012", Vilnius Lithuania, https://doi.org/10.3846/bm.2012.032 